\title{
Personality Traits as Predictors of Citizen Engagement with Local Government
}

\section{Victor G. Hugg*, Kelly LeRoux*}

\begin{abstract}
Do citizens' personality traits affect their likelihood of interacting with local public officials? Using psychology's preferred approach for operationalizing personality — the "Big Five" trait framework — and two nationally-representative survey data sets from the U.S., we examine this question, and find that: (1) citizens who score higher on openness and extraversion traits have an increased likelihood of attending a local government board meeting; and (2) personality traits that predict the likelihood a citizen will contact a local government official vary based on whether that official holds an elected or non-elected position. We conclude by discussing the implications of these findings for citizen engagement scholarship, and outline ways to extend this research in future studies.
\end{abstract}

Keywords: Personality traits, Big five, Local government participation, Citizen engagement

$\mathrm{C}$ itizen engagement is a topic of perennial importance for the field of public administration, and accordingly has been the subject of extensive research. Much of the work pertaining to this topic has focused on impacts or outcomes of engaging citizens (Yang \& Pandey, 2011), the challenges of participation (Fung, 2015), and identifying the "tools" of engagement or modes of communication through which citizens might increase their interaction with government (Bingham, Nabatchi, \& O'Leary, 2005; Edelenbos \& Klijn, 2005). While this research has yielded important insights, it has largely focused on organizational and institutional factors that shape participation. To the extent that individual-level considerations are factored into citizen engagement research, it has generally been to emphasize the role played by demographic characteristics such as age and education, in shaping both propensity to engage as well as quality of participatory outcomes.

Given the tendency to focus on citizen engagement largely from the vantage point of the public organization, far less scholarly attention within the field

\footnotetext{
* Department of Public Administration, University of Illinois at Chicago

Address correspondence to Victor G. Hugg at (hugg2@uic.edu)

Copyright: C 2019. The authors license this article under the terms of the Creative Commons Attribution 4.0 International License.
}

of public administration has been given to individuallevel questions (e.g., how personality might influence citizen engagement) despite the potential implications for the design of local citizen participation platforms and public officials' perceptions of citizens' preferences and values. Working through a behavioral public administration lens, we investigate in this paper the role of personality traits in influencing citizen engagement in local government. Grimmelikhuijsen and colleagues (2017) defined behavioral public administration as "the analysis of public administration from the micro-level perspective of individual behavior and attitudes by drawing on insights from psychology on the behavior of individuals and groups" (p. 45). In this study, we build on the existing literature related to the impact of personality traits on citizen participation, making a distinct contribution by examining the role of personality traits in influencing citizen engagement in local government.

The study of how personality traits influence various forms of citizen participation and engagement is not entirely new. Numerous studies from the field of political science have examined the role of personality traits on aspects of political participation (e.g., Schoen \& Schumann, 2007; Gerber, Huber, Doherty, Dowling, Raso, \& Ha, 2011) and more recently public administration scholars have consid- 
ered how these traits influence aspects of participation such as deliberative democracy (Choi, 2014) and coproduction (O'Brien, Offenhuber, Baldwin-Phillipi, Sands, \& Gordon, 2017). While citizen participation can assume many forms, we limit our analysis of participation to a set of vehicles designed for "giving citizens direct voice and an active role in civic governance" (World Bank, 2018). Specifically, we examine participation in local government meetings, and contacting of local elected and non-elected (administrative) public officials.

Personality traits have been under-utilized constructs in public administration research. As one exception, van Witteloostuijn, Esteve, \& Boyne (2017) examined the relationship between personality traits and public service motivation. In the world of public management practice, personality tests have been used by human resource departments as a job selection tool in both the public and private sector for many years, and indeed a meta-analysis examining the "Big Five" traits found personality to be predictors for some occupations (Barrick \& Mount, 1991; Barrick, Mount, \& Judge, 2001). While there are many obvious applications of personality traits to research involving public personnel management, shaping organizational culture, and other internal dimensions of management, we consider the implications that citizen personality traits might have for one external dimension of management - that of receiving feedback from the public through various forms of citizen engagement. We aim to contribute to the emerging behavioral public administration literature by addressing the question of how personality influences participation using psychology's preferred approach for operationalizing personality — the "Big Five" trait framework.

In the next section, we describe the "Big Five" framework and provide a brief overview of the existing political psychology literature that connects personality traits to political ideology, partisan identification, and policy preferences. Next, we outline our hypotheses, followed by a description of our data and methods. Our results reveal that certain personality traits can indeed predict citizen engagement with local government. We conclude with a brief discussion of the implications of these findings.

\section{The "Big Five" Framework}

An individual's personality is an internal psychological structure composed of multifaceted traits that persist in a stable form over one's lifetime (Costa \&
McCrae, 1992; Gosling, Rentfrow, \& Swann, 2003). Researchers in the field of psychology examine enduring traits, or an individual's psychological tendencies, by operating within a framework known as the "Big Five." To better categorize personal qualities, psychologists started with 4,500 dictionary words associated with traits and relied on factor analysis to reduce the number of words needed to satisfactorily capture a person's personality to the five used today (John, Naumann, \& Soto, 2008). This "five-factor" model progressively developed into what is now referred to as the "Five-Factor Theory," a scientific theory intended to encompass the current extent of scholarly knowledge concerned with human trait behavior (McCrae \& Costa, 2008). These five personality traits are:

1. Openness. Individuals who value new experiences and have an active imagination are considered open. Adjectives that describe open people include intellectual, complex, polished, unconventional, creative, and independent-minded.

2. Conscientiousness. Highly conscientious individuals would describe themselves as careful, orderly, self-disciplined, hard-working, responsible, and dependable.

3. Extraversion. Extraverts are outgoing, sociable, talkative, assertive, enthusiastic, and energetic.

4. Agreeableness. Agreeable people are described as good-natured, sympathetic, cooperative, warm, and trustful.

5. Neuroticism. Those who are neurotic, or low in emotional stability, easily become nervous, anxious, or upset. They are unable to handle stress well and have difficulty relaxing.

Political scientists have produced a substantial amount of research related to psychology and the Big Five in the past several decades. Sniderman (1975) found connections between an "open ego" and high amounts of self-esteem with what he called a "democratic personality." Caprara and colleagues (2006) found that voters who leaned left on the ideological spectrum scored high in measures of openness, but low in measures of conscientiousness (relative to those ideologically on the right). Schoen \& Schumann (2007) studied voting behavior in Germany and found that "personality traits indirectly affect partisan attitudes in predictable ways," concluding that: (1) voters who scored high on openness were more inclined to support political parties that favored socially-liberal policies; (2) those who scored low on 
Table 1

Summary of Hypothesized Relationships

\begin{tabular}{rccc}
\hline \hline & $\begin{array}{c}\text { Involved in Local Gov. } \\
\text { Meeting }\end{array}$ & $\begin{array}{c}\text { Contacted Elected } \\
\text { Local Gov. Official }\end{array}$ & $\begin{array}{c}\text { Contacted Non-Elected } \\
\text { Local Gov. Official }\end{array}$ \\
\hline Openness & + & + & + \\
Conscientiousness & + & + & + \\
Extraversion & + & + & + \\
Agreeableness & - & + & - \\
Neuroticism & - & - & + \\
\hline
\end{tabular}

conscientiousness also favored socially-liberal policies; and (3) those who scored high on neuroticism supported parties that offered "shelter against material or cultural challenges" (p. 471). Gerber and colleagues (2011) found correlations between personality traits and key measures of political participation, defined as "voting in general elections, participating in national political campaigns, and participating in local community affairs and politics" (p. 695). The authors found that the increase in political participation was associated with high extraversion and low neuroticism scores.

Much of the research that has made use of personality traits to answer administration-oriented questions has been conducted outside of the United States. For example, a study from Canada found that politicians and public servants "differ appreciably in some major personality characteristics" (Ashton, Kushner, \& Siegel, 2007, p. 286); scholars in the United Kingdom found that openness, conscientiousness, and extraversion were "generally positively associated with the propensity of individuals to become managers" (Georgellis \& Sankae, 2016, p. 67); and two studies of government workers in Taiwan and China found that certain traits influenced levels of public service motivation and task performance (Jiang, Wang, \& Zhou, 2009; Jang, 2012). While personality traits and the Big Five specifically have been under-utilized in public administration research, our analysis provides one example of the many ways these traits might be applied to questions of administration and management.

\section{Hypotheses}

Although we have no theoretical basis for expecting the relationship between personality traits and inclination to contact a local official to vary based on whether the official is elected or non-elected, we test these differences to determine whether personality differentially influences contacting behavior.

Since open individuals are self-reliant, less trustful of government administrators, and more willing to consider new ideas, we hypothesize that these citizens have a greater likelihood of becoming involved in a local government meeting, all else equal. Highly open people may also be more likely to reach out to government officials because they want their local decisionmakers to be aware of their preferences and to understand that they are being monitored by the electorate.

Scholars have previously suggested that conscientious people, as responsible citizens who feel a stronger sense of civic duty, are more likely to attend local government meetings and contact local officials about political issues than not, all else equal (Gerber et al., 2011, p. 696; Mondak \& Halperin, 2008, p. 356). Extraverts, being loquacious in nature, are likely to feel comfortable both at public meetings and with reaching out to government officials.

Though agreeable individuals may view local government forums positively for being a direct, collaborative form of democracy, they are more inclined to favor participatory approaches that are less conflict-prone. We therefore hypothesize that agreeable people are less likely to attend a local government meeting in favor of avenues with a decreased chance of interpersonal discord (e.g., reaching out to a government official). Finally, we suspect that to the extent they engage in public affairs at all, individuals with neurotic, emotionally unstable personalities prefer one-way interactions (e.g., contributing money to candidates or political organizations), eschewing both attending local government meetings (particularly if such experiences are perceived to be potentially contentious) and contacting local officials. 
Table 1 summarizes the hypothesized relationships between citizens' personality traits and our three engagement measures, with a plus sign indicating higher likelihood of engagement and a negative sign indicating lower likelihood.

\section{Data and Methods}

While experimental methods have served as the modus operandi for addressing behavioral public administration questions, some have cautioned that an over-reliance on this singular approach threatens to constrain the variety of research questions that scholars pursue (Moynihan, 2018). Citing numerous critiques on the limits of experiments, Moynihan (2018) points to the benefits of "a more pluralistic approach consistent with the broader methodological toolbox of psychology, which has devoted significant scholarly attention to descriptive tools, such as validated scales of personality" (p. 4).

Our study contributes to the methodological pluralism of the emerging behavioral public administration field through cross-sectional analyses of survey data from the 2012 and 2016 American National Election Studies (ANES). The ANES, developed and administered by the University of Michigan and Stanford University with funding from the National Science Foundation, is a dual-mode survey that aims to generate a nationally-representative sample by conducting both Internet surveys and face-to-face interviews. For the Internet mode, respondents were recruited using address-based sampling and randomdigit dialing, while face-to-face respondents were drawn from an address-based, stratified, multi-stage cluster sample. Although the ANES cumulative time series includes data spanning back to 1948, personality trait questions have only been included in the two most recent iterations of the questionnaire.

We examine three dependent variables in our analysis. Table 2 provides a detailed description of the variables' measurement. Because these are yes/no items, they are treated as binary variables. Wording and response items were identical in both 2012 and 2016 for the first dependent variable; the second and third dependent variables only exist on the 2016 ANES. ${ }^{1}$

The Big Five personality traits represent our key independent variables of interest. The traits are measured via indices based on respondents' mean scores on a ten-item personality inventory (TIPI). Table 3 provides a description of these variable measures.
For ease of interpretation, all trait results were recoded and linearly scaled from zero and one (Mondak, Hibbing, Canache, Seligson, \& Anderson, 2010). Accordingly, higher values indicate that the respondent loaded more on that dimension. Although the use of ten-item inventories is less than ideal, previous scholarly work has concluded that the need for preventing respondent fatigue outweighs the small loss in reliability (Gosling et al., 2003; Rammstedt \& John, 2006).

To enable comparison of the personality traits' effect sizes to traditional predictors of citizen engagement, we examined measures of trust, political efficacy, and social capital (which were similarly scaled from zero to one to enable comparison to the personality traits). These predictors were not included in our main models because they have been found to be influenced by personality traits, which would produce trait coefficients that are downwardly biased (Dinesen, Nørgaard, \& Klemmensen, 2014).

Political scientists have long ago confirmed that in addition to time and money, individuals require resources such as civic skills and capacities to participate in the political process (Brady, Verba, \& Schlozman, 1995). These capacities might include political efficacy, or a sense that one can influence government or policy-makers, generalized sense of trust in government and political institutions, and socialization influences such as professional networks, associations, or participation in civic groups (Rosenstone \& Hansen, 1993). While we were limited by the data available in the ANES, we were able to tap into each of these concepts in some way.

A single item Likert-type scale question was used to measure respondents' level of trust in government. For the trust variable, responses were recoded to ensure that stronger perceptions of government corruption corresponded to lower values. For political efficacy, responses from two questions were similarly recoded before creating a mean index. In 2012, respondents were randomly assigned to receive either the standard question wording (for comparison to previous ANES surveys) and a revised version aimed at reducing agree-disagree acquiescence bias. Since the revised version was dropped in 2016, we elected to use the respondents who encountered the standard phrasing from 2012. As a result, models that include the efficacy index have half the number of observations as models that do not. While the ANES did not contain any measures of professional associations or networks of influence, there is a measure of 
Table 2

\section{Measurement of Dependent Variables}

\begin{tabular}{rlc}
\hline \hline Variable & \multicolumn{1}{c}{ Survey Question } & Response Items \\
\hline $\begin{aligned} \text { Involved in } \\
\text { Local Gov. Meeting }\end{aligned}$ & "During the past 12 months, did you attend a meeting about & Yes, No \\
Contacted Local & "What about an elected official on the state or local level, & Yes, No \\
Elected Official & $\begin{array}{l}\text { such as a governor, mayor, or a member of the state legisla- } \\
\text { ture or city council, or someone on the staff of such an } \\
\text { elected official? Have you contacted such a person in the }\end{array}$ & \\
& past twelve months?" & \\
Contacted Local & "And what about a non-elected official in a state or local & Yes, No \\
Non-Elected Offi- & government agency? Have you contacted such a person in & \\
cial & the past twelve months?" & \\
\hline
\end{tabular}

Table 3

Measurement of Personality Trait Variables

\begin{tabular}{|c|c|}
\hline Variable & ANES 2012/2016 Survey Questions \\
\hline Openness & $\begin{array}{l}\text { open to new experiences, complex } \\
\text { conventional, uncreative }\end{array}$ \\
\hline Conscientiousness & $\begin{array}{l}\text { dependable, self-disciplined } \\
\text { disorganized, careless }\end{array}$ \\
\hline Extraversion & $\begin{array}{l}\text { extraverted, enthusiastic } \\
\text { reserved, quiet }\end{array}$ \\
\hline Agreeableness & $\begin{array}{l}\text { sympathetic, warm } \\
\text { critical, quarrelsome }\end{array}$ \\
\hline Neuroticism & $\begin{array}{l}\text { anxious, easily upset } \\
\text { calm, emotionally stable }\end{array}$ \\
\hline
\end{tabular}

volunteering, which is a common indicator of individual-level "bridging" or personal network-enhancing social capital (Saxton \& Benson, 2005). Therefore, social capital was measured through a binary indicator that reflects whether the respondent devoted any time to volunteer work in the past year. Table 4 summarizes the measurement of these constructs. Finally, we controlled for the respondents' race (coded as "1" if the respondent selected "white" and "0" otherwise), sex ("1" for female and "0" otherwise), and age (coded as a continuous measure in years).

Since the dependent variables are measured dichotomously, all models were estimated using logistic regression. The regression tables presented in this analysis follow the recommendations of both ANES code books and use weights to account for the probability of household selection, the probability of respondent selection within the household, non-response, and random sampling error. In addition, all regression tables report coefficients as odds ratios and use Taylor series adjustments to compute designconsistent standard errors. ${ }^{4}$

\section{Results}

Are certain personality traits associated with increased likelihood of participation in local government meetings? The results displayed in Table 5 help 
Table 4

Measurement of Non-Trait Variables

\begin{tabular}{|c|c|c|}
\hline Variable $^{3}$ & ANES 2012/2016 Survey Questions & Response Items \\
\hline Trust & $\begin{array}{l}\text { "How many of the people running the govern- } \\
\text { ment are corrupt?" }\end{array}$ & All, Most, About Half, A Few, None \\
\hline Efficacy & $\begin{array}{l}\text { "Public officials don't care much what people like } \\
\text { me think." / "People like me don't have any say } \\
\text { about what the government does." }\end{array}$ & $\begin{array}{l}\text { Agree Strongly, Agree Somewhat, } \\
\text { Neither Agree nor Disagree, Disagree } \\
\text { Somewhat, Disagree Strongly }\end{array}$ \\
\hline Volunteer & $\begin{array}{l}\text { "Many people say they have less time these days to } \\
\text { do volunteer work. What about you, were you able } \\
\text { to devote any time to volunteer work in the last } 12 \\
\text { months or did you not do so?" }\end{array}$ & Yes, No \\
\hline
\end{tabular}

Table 5

Involved in Local Government Board Meeting in the Past 12 Months $^{5}$

\begin{tabular}{|c|c|c|c|c|}
\hline \multirow[b]{2}{*}{ Openness } & \multicolumn{2}{|c|}{2012} & \multicolumn{2}{|c|}{2016} \\
\hline & $\begin{array}{l}2.471 \text { *** } \\
(0.633)\end{array}$ & - & $\begin{array}{l}2.424 * * * \\
(0.642)\end{array}$ & - \\
\hline Conscientiousness & $\begin{array}{c}1.147 \\
(0.298)\end{array}$ & - & $\begin{array}{c}1.102 \\
(0.326)\end{array}$ & - \\
\hline Extraversion & $\begin{array}{l}1.429 * \\
(0.284)\end{array}$ & - & $\begin{array}{l}1.423 * \\
(0.268)\end{array}$ & - \\
\hline Agreeableness & $\begin{array}{c}1.099 \\
(0.284)\end{array}$ & - & $\begin{array}{l}2.652 \text { *** } \\
(0.778)\end{array}$ & - \\
\hline Neuroticism & $\begin{array}{l}0.598 * * \\
(0.147)\end{array}$ & - & $\begin{array}{l}0.620 * * \\
(0.148)\end{array}$ & - \\
\hline Trust & - & $\begin{array}{c}1.492 \\
(0.492)\end{array}$ & - & $\begin{array}{c}1.149 \\
(0.264)\end{array}$ \\
\hline Efficacy & - & $\begin{array}{c}1.011 \\
(0.283)\end{array}$ & - & $\begin{array}{l}1.606 \text { ** } \\
(0.300)\end{array}$ \\
\hline Volunteer & - & $\begin{array}{l}4.571 * * * \\
(0.636)\end{array}$ & - & $\begin{array}{l}5.7622^{* * *} \\
(0.579)\end{array}$ \\
\hline White & $\begin{array}{l}0.844 * \\
(0.079)\end{array}$ & $\begin{array}{c}0.877 \\
(0.118)\end{array}$ & $\begin{array}{c}0.895 \\
(0.097)\end{array}$ & $\begin{array}{l}0.806 * \\
(0.089)\end{array}$ \\
\hline Female & $\begin{array}{c}0.952 \\
(0.084)\end{array}$ & $\begin{array}{c}0.972 \\
(0.124)\end{array}$ & $\begin{array}{c}1.079 \\
(0.107)\end{array}$ & $\begin{array}{c}1.135 \\
(0.117)\end{array}$ \\
\hline Age & $\begin{array}{c}1.001 \\
(0.002)\end{array}$ & $\begin{array}{c}1.000 \\
(0.004)\end{array}$ & $\begin{array}{c}1.003 \\
(0.003)\end{array}$ & $\begin{array}{l}1.007 * * \\
(0.003)\end{array}$ \\
\hline Log-Likelihood & -2986.774 & -1351.211 & -2057.423 & -1842.361 \\
\hline Pseudo-R ${ }^{2}$ & 0.018 & 0.107 & 0.021 & 0.126 \\
\hline Observations & 5395 & 2684 & 3445 & 3464 \\
\hline
\end{tabular}

*** $\mathrm{p}<0.01 ; * * \mathrm{p}<0.05 ; * \mathrm{p}<0.1$.

Coefficients are odds ratios. Taylor series standard errors in parentheses. 
Table 6

Contacted Local Government Official in the Past 12 Months $^{5}$

\begin{tabular}{|c|c|c|c|c|}
\hline & \multicolumn{2}{|c|}{ Elected Official } & \multicolumn{2}{|c|}{ Non-Elected Official } \\
\hline Openness & $\begin{array}{l}3.282 \text { *** } \\
(1.256)\end{array}$ & - & $\begin{array}{l}3.305 * * * \\
(1.510)\end{array}$ & - \\
\hline Conscientiousness & $\begin{array}{l}0.526 * \\
(0.180)\end{array}$ & - & $\begin{array}{c}0.597 \\
(0.263)\end{array}$ & - \\
\hline Extraversion & $\begin{array}{c}1.526 \\
(0.425)\end{array}$ & - & $\begin{array}{l}1.919 \text { ** } \\
(0.581)\end{array}$ & - \\
\hline Agreeableness & $\begin{array}{c}1.225 \\
(0.506)\end{array}$ & - & $\begin{array}{c}0.818 \\
(0.335)\end{array}$ & - \\
\hline Neuroticism & $\begin{array}{l}0.391 \text { *** } \\
(0.115)\end{array}$ & - & $\begin{array}{c}0.816 \\
(0.311)\end{array}$ & - \\
\hline Trust & - & $\begin{array}{c}1.508 \\
(0.378)\end{array}$ & - & $\begin{array}{l}2.523 * * \\
(0.941)\end{array}$ \\
\hline Efficacy & - & $\begin{array}{l}1.885^{* * *} \\
(0.446)\end{array}$ & - & $\begin{array}{c}1.497 \\
(0.457)\end{array}$ \\
\hline Volunteer & - & $\begin{array}{l}2.8855^{* * *} \\
(0.394)\end{array}$ & - & $\begin{array}{l}2.445 \text { *** } \\
(0.340)\end{array}$ \\
\hline White & $\begin{array}{l}1.493 \text { *** } \\
(0.226)\end{array}$ & $\begin{array}{l}1.456 \text { ** } \\
(0.230)\end{array}$ & $\begin{array}{l}1.611^{* * *} \\
(0.245)\end{array}$ & $\begin{array}{l}1.523 \text { *** } \\
(0.238)\end{array}$ \\
\hline Female & $\begin{array}{c}0.915 \\
(0.126)\end{array}$ & $\begin{array}{c}0.914 \\
(0.127)\end{array}$ & $\begin{array}{l}0.690^{* *} \\
(0.101)\end{array}$ & $\begin{array}{l}0.667^{* *} \\
(0.098)\end{array}$ \\
\hline Age & $\begin{array}{l}1.014 \text { *** } \\
(0.003)\end{array}$ & $\begin{array}{l}1.014^{* * *} \\
(0.004)\end{array}$ & $\begin{array}{l}1.024 \text { *** } \\
(0.004)\end{array}$ & $\begin{array}{l}1.022^{* * *} \\
(0.004)\end{array}$ \\
\hline Log-Likelihood & -1310.886 & -1271.463 & -1037.968 & -1016.292 \\
\hline Pseudo-R ${ }^{2}$ & 0.032 & 0.064 & 0.044 & 0.071 \\
\hline Observations & 3443 & 3461 & 3445 & 3463 \\
\hline
\end{tabular}

*** $\mathrm{p}<0.01 ; * * \mathrm{p}<0.05 ;{ }^{*} \mathrm{p}<0.1$.

Coefficients are odds ratios. Taylor series standard errors in parentheses.

Table 7

Summary of Hypothesized Relationships and Results

\begin{tabular}{lcccccc}
\hline \hline & \multicolumn{2}{c}{$\begin{array}{c}\text { Involved in } \\
\text { Local Gov. Meeting }\end{array}$} & $\begin{array}{c}\text { Contacted } \\
\text { Local Gov. Official }\end{array}$ & \multicolumn{2}{c}{$\begin{array}{c}\text { Contacted Non-Elected } \\
\text { Local Gov. Official }\end{array}$} \\
\cline { 2 - 7 } & $\begin{array}{c}\text { Hypothe- } \\
\text { sized Rela- } \\
\text { tionship }\end{array}$ & $\begin{array}{c}\text { Hypothesis } \\
\text { Supported }\end{array}$ & $\begin{array}{c}\text { Hypothe- } \\
\text { sized Rela- } \\
\text { tionship }\end{array}$ & $\begin{array}{c}\text { Hypothesis } \\
\text { Supported }\end{array}$ & $\begin{array}{c}\text { Hypothe- } \\
\text { sized Rela- } \\
\text { tionship }\end{array}$ & $\begin{array}{c}\text { Hypothesis } \\
\text { Supported }\end{array}$ \\
\hline Openness & + & Yes & + & Yes & + & Yes \\
Conscientiousness & + & No & + & No & + & No \\
Extraversion & + & Yes & + & No & + & Yes \\
Agreeableness & - & No & + & No & + & No \\
Neuroticism & - & Yes & - & Yes & - & No \\
\hline
\end{tabular}


to answer this question. For all five personality traits in both years, the coefficients mirror the hypotheses. Compared to individuals with the lowest openness score, the most highly-open citizens are 2.4 times more likely to attend a local board meeting, all else equal $(\mathrm{p}<0.01)$. Similarly, moving from the least to most extraverted person increases the probability of attendance by approximately $42 \%(p<0.1)$. Neuroticism decreases the chance of participating in a local government meeting by around $40 \%$. Agreeableness only achieved statistical significance in the 2016 sample of respondents.

Our analysis also yields some findings in terms of the control variables. We find inconsistent effects of the role of age and political efficacy, with both having a positive impact on participation but in the 2016 sample only. We do find consistent effects of the impact of social capital created through voluntary action however: respondents who volunteered in their community are between 4.5 and 5.7 times more likely to participate in a local government meeting ( $\mathrm{p}$ $<0.01)$, all else being equal.

Our second research question asked whether personality traits shape citizen contact of local government officials. The results displayed in Table 6 show that the answer, for certain traits, is contingent on whether the official in question holds an elected or non-elected position. Nearly every coefficient aligns with our theorized expectation, though only one trait achieved statistical significance for both types of officials.

As hypothesized, those who have more open personality traits - intellectual, complex, openminded - are more likely to contact a local official, whether elected or not $(p<0.01)$. Extraverts are also more likely $(p<0.05)$ to contact a non-elected local official. The explanation for this is not entirely clear, but one possibility is that non-elected officials (public administrators) are perceived as having more time and willingness to listen to citizens and engage in discussion with them since they are more stable fixtures of local government whereas elected officials may be viewed as temporary and less worth the citizen's time to cultivate a relationship. Conscientiousness people are less likely to contact a local elected official ( $\mathrm{p}<$ $0.1)$. It may be the case that conscientious personalities are sufficiently absorbed in other life responsibilities to prioritize contact with local officials. These same individuals are those who may feel most compelled to be fully informed about an issue before contacting a local government professional and inhibited about making contact if they have not taken the time to thoroughly research an issue or public matter.

Extraverts, on the other hand, may be unconstrained by these inhibitions and simply assert their comments, questions, or grievances without as much thought or consideration. Respondents who agreed that they became nervous easily were, as anticipated, less likely to contact an elected local official ( $p<0.01$ ). However, neuroticism appears to have no impact on likelihood of contacting an administrative official.

The agreeableness trait was not statistically significant for contacting either type of public official.

Demographics play a predictable role in the contacting of local officials. For issues that strike close to home, a person's age is positively associated with attending a local government meeting. This finding is consistent with decades of evidence that political participation in every form is dominated by older citizens (Brady et al., 1995). Race also has a consistent effect on contacting as a form of citizen engagement, with white citizens being statistically significantly more likely to initiate contact with both elected and administrative local officials. Beyond demographics, volunteering also consistently predicts contacting of local public officials, both elected and non-elected. The remaining control variables demonstrate more mixed influences.

Ultimately, the extent to which personality traits influence local citizen engagement appears to vary by trait and type of engagement. Table 7 offers a summary of our hypotheses about the role of personality traits and which ones were confirmed.

\section{Implications and Conclusions}

Overall, we conclude that three personality traits the dimensions of openness, extraversion, and neuroticism - appear to be particularly relevant when considering questions of local citizen engagement; these traits achieved varying levels of statistical significance in all four models. Thus, public officials' perceptions of citizens' preferences and values may be biased, or at the very least constrained, by the type of people who participate. Open and extraverted citizens, while most likely to participate in local government, may not hold policy views that are representative of the entire electorate; indeed, those who are more conventional or reserved - personality traits opposite to openness and extraversion - may hold different policy preferences that largely fail to get transmitted to public officials. Similarly, the tendency 
of neurotic citizens to avoid contact with elected officials raises questions about how these officials might tap the perspectives of this silent segment of the population. Gaining feedback from a wide variety of citizen personality types is important, so as to identify pockets of latent dissatisfaction (or approval) and thus, design local policies and programs accordingly.

These findings may have implications for the design and implementation of local citizen participation platforms. While the ANES does not differentiate whether contacting of local officials is done online, in-person, or by phone, our results speak to the importance of local governments maintaining a multi-modal approach to citizen participation vehicles. Research on the use of e-government and e-participation technologies in local governments has proliferated in recent years, and a central assumption underlying the adoption of these technologies, especially two-way communication like social media, is that it makes for more inclusive participation (Tolbert \& Mossberger, 2012; Li \& Feeney, 2014). Yet given the diversity of personality types in the electorate, local governments must take care not to become too reliant on online technologies or any other single vehicle for obtaining citizen input and participation. While e-participation technologies may indeed expand options for citizens to participate, local governments should not abandon the "old" vehicles through which citizens might engage. Although many local officials may prefer to field inquiries only by email, extraverted citizens may only be inclined to contact if they can pick up the phone and talk with someone. In the same way, some personality types will avoid participation in a public meeting in person, but may be inclined to engage via YouTube channel recording or via online streaming of the meeting when an issue of interest is on the agenda. Public managers and local elected officials should challenge themselves to think about diversity in the population beyond conventional demographic measures and consider how diverse personalities can be accommodated and encouraged to participate.

Our study is not without limitations. First, variation that may exist between local areas could not be examined. Since questionnaires conducted nationally are more often used to answer questions where the country is the unit of analysis, this study can only render broad generalizations. Second, using a ten-item personality inventory limits the potential range and granularity of variance in the data. Although scholars have found a ten-item battery to strike an acceptable balance between reliability and preventing respondent fatigue, gaining a greater degree of variability from a longer questionnaire - even at the expense of a smaller sample size - may be a satisfactory tradeoff for some researchers.

Despite these limitations, this study takes a small step toward a better understanding of how diversity among citizen personalities influences the likelihood of engaging with local government. While our study was focused on how citizen's personality traits shape their propensity for interacting with local government, we can envision many ways that personality traits might be usefully applied in public administration research. Understanding the personality traits of government administrators, ranging from public managers to street-level bureaucrats, carries potentially significant implications for organizational theory. Being able to infer the personality of various actors in an organization - as well as the potential interaction effects of emotion, race, and gender on their cognitive processing - could reveal new and important insights for public managers about both the internal and external dimensions of managing and leading public organizations. We encourage other scholars to reflect on ways that personality traits might be relevant to the study of public management questions and to engage these constructs when theoretically indicated.

\section{Notes}

1. For summary statistics, refer to Appendix A and B.

2. The personality trait questions asked on both ANES surveys were worded as follows: "We're interested in how you see yourself. Please mark how well the following pair of words describes you, even if one word describes you better than the other." Respondents answered using a seven-item Likert-scale ranging from "Extremely Poorly" to "Extremely Well."

3. Questions pertaining to the race, sex, and age of respondents were not included in either code book.

4. ANES documentation specifies: "To obtain correct standard errors and significance tests, set up your software to use Taylor series estimation."

5. Log-likelihood and pseudo- $\mathrm{R}^{2}$ statistics were calculated without weights under simple random sampling assumptions. They are included only for reference. 


\section{References}

Alford, J. R., Funk, C. L., \& Hibbing, J. R. (2005). Are political orientations genetically transmitted? American Political Science Review, 99(2), 153-167.

Ashton, M., Kushner, J., \& Siegel, D. (2007). Personality traits of municipal politicians and staff. Canadian Public Administration, 50(2), 273-289.

Barrick, M. R. \& Mount, M. K. (1991). The big five personality dimensions and job performance: A meta-analysis. Personnel Pychology, 44, 1-26.

Barrick, M. R., Mount, M. K., \& Judge, T. A. (2001). Personality and performance and the beginning of the new millenium: What do we know and where do we go next? International Journal of Selection and Assessment Performance, 9(1/2), 9-29.

Bingham, L. B., Nabatchi, T., \& O'Leary, R. (2005). The new governance: Practices and processes for stakeholder and citizen participation in the work of government. Public Administration Review, 65(5), 547558.

Brady, H. E., Verba, S., \& Schlozman, K. L. (1995). Beyond SES: A resource model of political participation. American Political Science Review, 89(2): 271-294.

Caprara, G. V., Schwartz, S., Capanna, C., Vecchione, M., \& Barbaranelli, C. (2006). Personality and politics: Values, traits, and political choice. Political Psychology, 27(1), 1-28.

Choi, T. (2014). Rational and compassionate information processing: A conceptual framework for authentic dialogue. Public Administration Review, 74(6): 726-735.

Costa, P. T. \& McCrae, R. R. (1992). Four ways five factors are basic. Personality and Individual Differences, 13(6), 653-665.

Dinesen, P. T., Nørgaard, A. S., \& Klemmensen, R. (2014). The civic personality: Personality and democratic citizenship. Political Studies, 62(S1), 134-152.

Eaves, L. J. \& Hatemi, P. K. (2008). Transmission of attitudes toward abortion and gay rights: Effects of genes, social learning and mate selection. Behavior Genetics, 38(3), 247-256.

Edelenbos, J. \& Klijn, E. H. (2005). Managing stakeholder involvement in decision making: A comparative analysis of six interaction processes in the Netherlands. Journal of Public Administration Research and Theory, 16(3), 417-446.

Fowler, J. H., Baker, L. A., \& Dawes, C. T. (2008). Genetic variation in political participation. American Political Science Review, 102(2), 233-248.

Fung, A. (2015). Putting the public back into governance: The challenges of citizen participation and its future. Public Administration Review, 75(4), 513-522.

Georgellis, Y. \& Sankae, N. (2016). The personality of managers in Britain: Gender and sector differences. Evidence-Based HRM: A Global Forum for Empirical Scholarship, 4(1), 67-80.
Gerber, A. S., Huber, G. A., Doherty, D., Dowling, C. M., Raso, C., \& Ha, S. E. (2011). Personality traits and participation in political processes. Journal of Politics, 73(3), 692-706.

Gosling, S. D., Rentfrow, P. J., \& Swann, W. B. (2003). A very brief measure of the big-five personality domains. Journal of Research in Personality, 37(6), 504-528.

Grimmelikhuijsen, S., Jilke, S., Olsen, A. L., \& Tummers, L. (2017). Behavioral public administration: Combining insights from public administration and psychology. Public Administration Review, 77(1), 45-56.

Hatemi, P. K., Gillespie, N. A., Eaves, L. J., Maher, B. S., Webb, B. T., Heath, A. C., \& Martin, N. G. (2011). A genome-wide analysis of liberal and conservative political attitudes. Journal of Politics, 73(1), 271-285.

Hatemi, P. K., Medland, S. E., \& Eaves, L. J. (2009). Do genes contribute to the "gender gap"? Journal of Politics, 71(1), 262-276.

Jang, C. (2012). The effect of personality traits on public service motivation: Evidence from Taiwan. Social Behavior and Personality, 40(5), 725-733.

Jiang, C., Wang, D., \& Zhou, F. (2009). Personality traits and job performance in local government organizations in China. Social Behavior and Personality, 37(4), 451-457.

John, O. P., Naumann, L. P., \& Soto C. J. (2008). Paradigm shift to the integrative big five trait taxonomy: History, measurement, and conceptual issues. In O. P. John, R. W. Robins, \& L. A. Pervin (Eds.), The handbook of personality: Theory and research (3rd ed.) (pp. 114-158). New York: Guilford.

Li, M.-H. \& Feeney, M. K. (2014). Adoption of electronic technologies in local U.S. governments: Distinguishing between e-services and communication technologies. The American Review of Public Administration, 44 (1), 75-91.

McCrae, R. R. \& Costa, Jr., P. T. (2008). The five-factor theory of personality. In O. P. John, R. W. Robins, \& L. A. Pervin (Eds.), The handbook of personality: Theory and research (3rd ed.) (pp. 159-181). New York: Guilford.

Mondak, J. J. \& Halperin, K. D. (2008). A framework for the study of personality and political behavior. British Journal of Political Science, 38(2), 335-362. https://doi.org/10.1017/S0007123408000173

Mondak, J. J., Hibbing, M. V., Canache, D., Seligson, M. A., \& Anderson, M. R. (2010). Personality and civic engagement: An integrative framework for the study of trait effects on political behavior. American Political Science Review, 104(1), 85-110.

Moynihan, D. (2018). A great schism approaching? Towards a micro and macro public Administration. Journal of Behavioral Public Administration, 1(1): 1-8. 
O'Brien, D. T., Offenhuber, D., Baldwin-Philippi, J., Sands, M., \& Gordon, E. (2017). Uncharted territoriality in coproduction: The motivations for 311 reporting. Journal of Public Administration Research and Theory, Volume 27(2): 320-335.

Oxley, D. R., Smith, K. B., Alford, J. R., Hibbing, M. V., Miller, J. L., Scalora, M., Hatemi, P. K., \& Hibbing, J. R. (2008). Political attitudes vary with physiological traits. Science, 321(5896), 1667-1670.

Perry, J. L. \& Wise, L. R. (1990). The motivational bases of public service. Public Administration Review, 50(3), 367-373.

Rammstedt, B. \& John, O. P. (2007). Measuring personality in one minute or less: A 10-item short version of the big five inventory in English and German. Journal of Research in Personality, 41(1), 203-212.

Rosentone, S. J. \& Hansen, J. M. (1993). Mobilization, participation, and democracy in America. New York: Macmillan Publishing Company.

Saxton, G. D. \& Benson, M. (2005). Social capital and the growth of the nonprofit sector. Social Science Quarterly, 86(1): 16-35.
Schoen, H. \& Schumann, S. (2007). Personality traits, partisan attitudes, and voting behavior. Evidence from Germany. Political Psychology, 28(4), 471-498.

Sniderman, P. M. (1975). Personality and democratic politics. In Personality and democratic politics. Berkeley, CA: University of California Press.

Tolbert, C. J. \& Mossberger, K. (2006). The effects of eGovernment on trust and confidence in government. Public Administration Review, 66(3): 354-369.

Van Witteloostuijn, A., Esteve, M., \& Boyne, G. (2017). Public sector motivation ad fonts: Personality traits as antecedents of the motivation to serve the public interest. Journal of Public Administration Research and Theory, 27 (1): 20-35.

Verhulst, B., Eaves, L. J., \& Hatemi, P. K. (2011). Correlation not causation: The relationship between personality traits and political ideologies. American Journal of Political Science, 56(1), 34-51.

Yang, K. \& Pandey, S. K. (2011). Further dissecting the black box of citizen participation: When does citizen involvement lead to good outcomes? Public Administration Review, 71(6), 880-892.

\section{Appendix A \\ Summary Statistics, ANES 2012}

\begin{tabular}{rccccc}
\hline & Obs. & Mean & Std. Dev. & Min. Value & Max. Value \\
\hline Involved in Local Gov. Meeting & 5,508 & 0.252 & 0.434 & 0 & 1 \\
Openness & 5,490 & 0.642 & 0.190 & 0 & 1 \\
Conscientiousness & 5,492 & 0.769 & 0.188 & 0 & 1 \\
Extraversion & 5,487 & 0.521 & 0.212 & 0 & 1 \\
Agreeableness & 5,490 & 0.688 & 0.182 & 0 & 1 \\
Neuroticism & 5,487 & 0.341 & 0.205 & 0 & 1 \\
White & 5,885 & 0.596 & 0.491 & 0 & 1 \\
Female & 5,914 & 0.519 & 0.500 & 0 & 1 \\
Age & 5,854 & 49.442 & 16.822 & 17 & 90 \\
Government Not Corrupt & 5,799 & 0.523 & 0.227 & 0 & 1 \\
Efficacy Index & 2,769 & 0.389 & 0.255 & 0 & 1 \\
Devote Time to Volunteering & 5,504 & 0.445 & 0.497 & 0 & 1 \\
\hline
\end{tabular}

\section{Appendix B}

Summary Statistics, ANES 2016 


\begin{tabular}{rccccc}
\hline \hline & Obs. & Mean & Std. Dev. & Min. Value & Max. Value \\
\hline Involved in Local Gov. Meeting & 3,642 & 0.300 & 0.458 & 0 & 1 \\
Contacted Elected Local Official & 3,639 & 0.133 & 0.340 & 0 & 1 \\
Contacted Non-Elected Local Official & 3,640 & 0.095 & 0.293 & 0 & 1 \\
Openness & 3,589 & 0.675 & 0.187 & 0 & 1 \\
Conscientiousness & 3,595 & 0.783 & 0.187 & 0 & 1 \\
Extraversion & 3,590 & 0.537 & 0.230 & 0 & 1 \\
Agreeableness & 3,589 & 0.700 & 0.190 & 0 & 1 \\
Neuroticism & 3,597 & 0.338 & 0.210 & 0 & 1 \\
White & 4,238 & 0.717 & 0.451 & 0 & 1 \\
Female & 4,219 & 0.529 & 0.499 & 0 & 1 \\
Age & 4,150 & 49.576 & 17.581 & 18 & 90 \\
Eovernment Not Corrupt & 4,223 & 0.478 & 0.221 & 0 & 1 \\
Efficacy Index & 3,630 & 0.394 & 0.255 & 0 & 1 \\
Devote Time to Volunteering & 3,637 & 0.444 & 0.497 & 0 & 1
\end{tabular}

